\title{
Sarcopenia screening in elderly in primary health care: nurse knowledge and practices
}

\author{
Rastreio da sarcopenia em idosos na atenção primária à saúde: saberes e práticas do enfermeiro
}

Detección de la sarcopenia en ancianos en la Atención Primaria de Salud: saberes y prácticas del enfermo

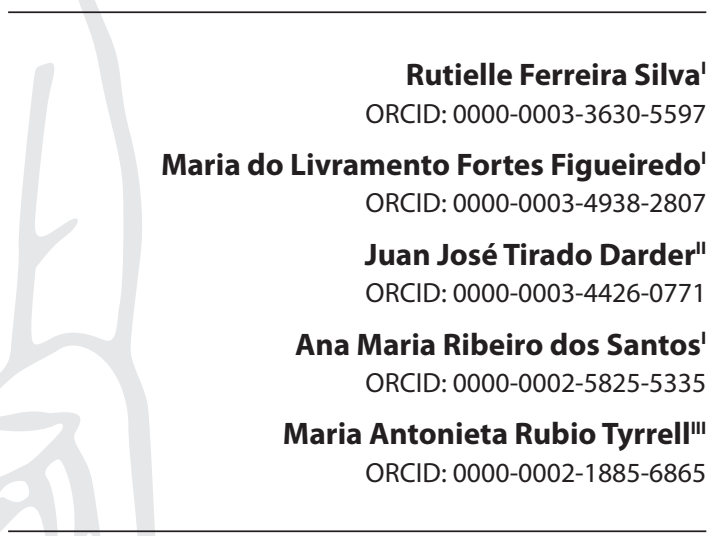

' Universidade Federal do Piauí. Teresina, Piauí, Brazil. "Universidad Europea de Valencia. València, Valencia. Espanha. '" Universidade Federal do Rio de Janeiro. Rio de Janeiro, Rio de Janeiro, Brazil.

How to cite this article: Silva RF, Figueiredo MLF, Darder JJT, Santos AMR, Tyrrell MAR. Sarcopenia screening in elderly in primary health care: nurse knowledge and practices. Rev Bras Enferm. 2020;73(Suppl 3):e20200421. doi: http://dx.doi.org/10.1590/0034-7167-2020-0421

\section{Corresponding author:} Rutielle Ferreira Silva E-mail: rutielle.rfs@gmail.com

EDITOR IN CHIEF: Antonio José de Almeida Filho ASSOCIATE EDITOR: Ana Fátima Fernandes

Submission: 06-30-2020

\section{ABSTRACT}

Objective: Describe the knowledge and practices of the Primary Health Care nurse on sarcopenia screening in the elderly. Methods: Qualitative study conducted with 24 Primary Health Care nurses. The data was collected through semi-structured interviews, recorded and later transcribed. The speeches were grouped in thematic categories, later analyzed, supported by Paulo Freire's reference. Results: The findings showed that the primary care nurses'knowledge of sarcopenia screening in the elderly was incipient and fragile. This reality is reflected in a gap in practice, although some instruments already require the registration of characteristics indicative of sarcopenia, such as the evaluation of the calf circumference. Final considerations: The need to train nurses to perform sarcopenia screening and to implement a promotional and preventive care plan, which will result in improving the quality of life of the elderly assisted in Primary Care, was highlighted.

Descriptors: Sarcopenia; Elderly; Geriatric Nursing; Primary Health Care; Mass Screening.

\section{RESUMO}

Objetivo: Descrever os saberes e as práticas do enfermeiro da Atenção Primária à Saúde sobre o rastreio da sarcopenia em idosos. Métodos: Estudo qualitativo realizado com 24 enfermeiros da Atenção Primária à Saúde. Os dados foram coletados mediante entrevistas semiestruturadas, gravadas e posteriormente transcritas. As falas foram agrupadas em categorias temáticas, posteriormente analisadas, apoiadas no referencial de Paulo Freire. Resultados: Os achados evidenciaram que os saberes dos enfermeiros da Atenção Primária referentes ao rastreio da sarcopenia em idosos mostraram-se incipientes e frágeis. Essa realidade reflete-se em uma lacuna na prática, embora alguns instrumentos já exijam o registro de características indicativas da sarcopenia, como a avaliação da circunferência da panturrilha. Considerações finais: Evidenciou-se a necessidade de capacitação dos enfermeiros para a efetivação do rastreio da sarcopenia e implementação de um plano de cuidados promocionais e preventivos, que resultará na melhoria da qualidade de vida dos idosos assistidos na Atenção Primária.

Descritores: Sarcopenia; Idoso; Enfermagem Geriátrica; Atenção Primária à Saúde; Programas de Rastreio.

\section{RESUMEN}

Objetivo: Describir saberes y prácticas del enfermero en la Atención Primaria de Salud sobre la detección de sarcopenia en ancianos. Métodos: Estudio cualitativo realizado con 24 enfermeros en la Atención Primaria de Salud. Los datos cogidos mediante entrevistas semiestructuradas, grabadas y posteriormente transcritas. Deposiciones agrupadas en categorías temáticas, posteriormente analizadas, apoyadas en Paulo Freire. Resultados: Hallados evidenciaron que saberes de enfermeros en la Atención Primaria referentes a la detección de sarcopenia en ancianos mostraron incipientes y débiles. Esa realidad refleja una laguna en la práctica, aunque algunos instrumentos ya habían el registro de características indicativas de sarcopenia, como la evaluación de la circunferencia de las pantorrillas. Consideraciones finales: Evidenció la necesidad de capacitación de los enfermeros para la efectuación de la detección de sarcopenia e implementación de un plan de cuidados promocionales y preventivos, que resultará en mejoría de calidad de vida a los ancianos asistidos en la Atención Primaria.

Descriptores: Sarcopenia; Anciano; Enfermería Geriátrica; Atención Primaria de Salud; Tamizaje Masivo. 


\section{INTRODUCTION}

In Brazil, the transition of the age pyramid has occurred in an accelerated manner compared to developed countries. In the country, the relative participation of the population above 60 years of age has grown from $9.8 \%$ in 2005 to $14.3 \%$ in 2015 and will reach $23.5 \%$ in $2039^{(1)}$. It is estimated that, in 2030 , the average life expectancy of Brazilians is 79 years $^{(2)}$.

The increase in life expectancy is accompanied by changes in the health profile of the population, in which chronic-degenerative diseases and functional disabilities stand out. Among the diseases that are installed as a result of the aging process and that are responsible for disability and dependence, sarcopenia, a progressive and generalized musculoskeletal disease, which has repercussions on the functional abilities of the elderly, that is, on their ability to perform their Activities of Daily Living $(A D L)^{(3)}$.

The elderly population is the most susceptible to the changes resulting from the disease, since with aging there is a gradual decline in strength and muscle mass, which will increase the risk of falls and fractures, reduced quality of life and increased mortality. The presence of sarcopenia increases the length of stay, and health care costs are significantly higher for people with sarcopenia compared to individuals without the disease $\mathrm{e}^{(3-6)}$.

It is considered a geriatric disease of high prevalence and difficult to diagnose, having relation with aging, presence of chronic diseases, nutritional deficits and lifestyle ${ }^{(3)}$. It is shown that, in the Brazilian population, the prevalence of the disease is $17 \%$ in women and $28.8 \%$ in men $^{(7)}$. In a survey conducted with 219 institutionalized elderly, the prevalence of sarcopenia was 32\% for those with good physical and cognitive conditions and $63.2 \%$ for the elderly regardless of their physical and/or cognitive capacity ${ }^{(8)}$.

Sarcopenia affects approximately $14 \%$ of individuals aged 60 years or older; about 1 in 10 elderly people are at risk to develop it, in the so-called pre-clinical stage ${ }^{(9)}$. It is emphasized that the prevalence of the disease will continue to grow as the proportion of elderly people rises; and, because it is a silent clinical condition, it is crucial that its development be prevented ${ }^{(3,10-11)}$. In this perspective, nurses who work in Primary Care have a fundamental role in the implementation of promotional, preventive and screening actions of the disease.

It is recommended to use the SARC-F questionnaire as a screening method for sarcopenia when signs and symptoms of falling, feeling of weakness, slow walking speed, difficulty in getting up from a chair, weight or muscle mass loss are reported by the user ${ }^{(3,9,12)}$. Another method available for this purpose is the evaluation of the Calf Circumference (CC), a tool that, according to the European Working Group on Sarcopenia in Older People (EWGSOP) protocol, should be used only in situations where the standard screening tool is not available(3).

Proper sarcopenia screening will enable this professional to plan interventions in a way that minimizes the adverse health outcomes of the elderly person and, consequently, will enable the reduction of costs to health services, promoting, above all, successful aging ${ }^{(3,12-17)}$.

Although it is a geriatric disease described more than two decades ago, there are still gaps in relation to it, especially regarding the practice developed by the nurse regarding screening. It is imperative to make these professionals and managers aware of the importance of prevention, screening and constant vigilance in relation to the disease, as prerequisites for improving the quality of life of the elderly.

\section{OBJECTIVE}

Describe the knowledge and practices of the Primary Health Care nurse on sarcopenia screening in the elderly.

\section{METHODS}

\section{Ethical aspects}

The research started after the approval of the Ethics and Research Committee of Federal University of Piauí, according to the principles described in the Resolution 466/2012 of the National Health Council(18). Participants have consented to participate in the research by signing the Free and Informed Consent Term.

\section{Theoretical-methodological reference}

The study is based on Paulo Freire's Dialectic Theory ${ }^{(19-20)}$, which is based on the dialogic and problematizing character of human relations and awareness, which is in a permanent process of learning. Based on Freire's liberating dialogue, it was possible to establish communication, a relationship of reciprocity and respect with the participants of the study, thus allowing the search in the work universe of the nurses for the knowledge and practices dispensed in the screening of sarcopenia from the perspective of transforming the reality in which they are inserted.

\section{Type of study}

Descriptive study with a qualitative approach. This method was chosen to present the universe of meanings, working with a reality that cannot be quantified. This is in line with the methodological proposal used in the study, which aims both to know the knowledge and practices of people inserted in a social, historical and cultural context and the effects of meaning produced ${ }^{(21)}$. The Consolidated Criteria for Reporting Qualitative Research (COREQ) checklist was used to guide the development of the research.

\section{Methodological procedures}

\section{Research Scenario}

The study was carried out in the area of Basic Health Units (BHU) of the Municipal Health Secretary of the city of Timon, a city in the state of Maranhão, located in the Northeast Region of Brazil. The municipality has 38 BHUs in the urban area, where 47 Family Health Strategy teams are inserted.

\section{Data source}

Nurses working in the Family Health Strategy (ESF) teams of the urban area of the city-scenario of the study participated in the study. The number of nurses in that city is 57 professionals, 47 of whom are stationed in the urban area. The participants were 
selected according to their interest and availability to participate in the survey. There was no temporal delimitation of the nurses' work relationship, considering that, during the data collection period, $50 \%$ of the quantitative of professionals had been replaced.

Those who worked exclusively in administrative activities were excluded, as well as those who were on vacation or on leave during the data production period. Therefore, of the 47 nurses in the urban area, three were on leave, 17 did not accept to participate, and three teams were without nurses. Thus, 24 nurses composed the study sample.

\section{Data collection and organization}

The data collection process took place from May to July 2019. The semi-structured script, used in the interviews, was elaborated by the researchers and presented the following open questions to guide the interviews: What do you understand by sarcopenia? What practices do you develop at ESF in relation to sarcopenia screening in the elderly? Do you use any algorithm/protocol/flowchart to evaluate the muscle mass, muscle strength or resistance of the elderly person? How often is the measurement of the calf of the elderly performed? And when it is checked, it is noted in the old man's notebook? In order to improve the script, a pre-test was conducted with five nurses - the pre-test in qualitative research consists of conducting interviews with some participants. This contributed to make clearer and more precise the list of topics and aspects to be addressed during field work ${ }^{(21)}$.

At the first moment, the participants received the invitation, which explained the purpose of the research, the expected benefits and the destination of the statements provided. After the invitation was confirmed, the principal investigator scheduled the day and time of the interview, according to the availability of each professional. The interviews were carried out individually, at the participants' location, and lasted approximately 20 to 30 minutes. The interviews were recorded in a digital recorder and later transcribed in the Microsoft Word 2016 program. The anonymity of the professionals was preserved by the use of the letter " $E$ ", followed by the cardinal numeral referring to the sequence of the interviews.

\section{Data analysis}

The systematization and analysis of the data were carried out based on the operationalization of the thematic analysis ${ }^{(20)}$. Initially, a careful reading of the transcribed testimonies was carried out in order to identify the nuclei of meaning of the participants' statements that make up the communication whose frequency or presence has significance for the analytic object in question. Then, the data were treated in such a way as to be meaningful and valid, with the interaction and interpretation being carried out in the light of the current reference framework pertinent to the theme, with the aim of raising discussions and removing the truthfulness of the data obtained from the research.

\section{RESULTS}

The participants were mostly female $(n=21)$, aged between 23 and 44 years, while the training time ranged from five months to 15 years. It is evident that 23 interviewees never participated in training in the area of gerontology.

The testimonies of the participants of the study showed two tendencies about the problem: some are conceptually unaware of sarcopenia in the elderly, including in their professional practice; and others know about sarcopenia although in a fragile and incipient way.

In the first trend, it is possible to see that the interviewees justify not having knowledge about the definition of sarcopenia in several ways: they claim not to know, not to have seen it at graduation - and another participant tried to mean it through the morphological analysis of the word "sarcopenia", as the following statements demonstrate:

Actually, I don't know about. (E4)

[...] I didn't know it yet, at my graduation it was little talked about the health of the elderly. (E1)

[...] when we have the ending "-penia" usually means the decrease, and "sarco-" has to do with the muscle cells, then it must be some loss, decrease something like. (E2)

In this same trend, it is perceived that the participants had some forms of knowledge in relation to sarcopenia, although it is seen that the knowledge is fragile, empirical, incomplete and ephemeral, which leads to failures in the process of screening for the disease, as recorded in the statements below:

I understand that when the person is already in the third age he diminishes his strength, everything becomes more fragile. And sarcopenia means a weakness in the muscles of the elderly and many times we don't notice. (E16)

It's just a matter of muscle weakness in the elderly, because of sarcopenia the elderly can have many falls [...]. (E18)

It is something in relation to the muscular wear of the elderly. (E13)

Sarcopenia is only the loss of muscle strength in the elderly. (E9)

Professionals show divergences of knowledge regarding sarcopenia. This concept was conceived both in a distorted and absent manner. However, some knowledges proved to be congruent with its real definition and applicability to the human condition of the elderly, as demonstrated in the following statements:

It is the loss of muscle strength. The old man loses his muscular mass and with it he will lose his strength. (E8)

Sarcopenia is the loss of strength or muscle mass in the elderly, so it brings with it the question of dependency [...]. (E14)

The analysis of the testimonies shows that the weaknesses in the nurses' knowledge about the definition of sarcopenia are reflected in the lack of knowledge of the practices, algorithms and protocols aimed at screening for the disease, as shown in the following speeches:

[...] this practice we don't develop [...] for lack of really knowledge. (E19) 
No, because I don't know how to do this practice. (E5)

I can't tell you any way of tracking. (E21)

That I know here, there is none, no scale like this to assess. (E11)

Specifically in relation to the practice of CC assessment as a method of sarcopenia screening, the nurses' speeches show that this assessment is not used, even though it is listed in the Elderly Person Health Booklet (CSPI - Caderneta de Saúde da Pessoa (dosa). There are several reasons for this: from not knowing how to do it, to prioritizing other chronic problems suffered by the elderly. Thus, it is also registered that the practices directed to the elderly are assistematic and fragmented, detaching from the protocols and policies directed to the elderly and to the screening of sarcopenia, as verified in the statements:

I don't check, as it is a not very comprehensive issue and in Basic Care we take care more focused on the prevention of diabetes and hypertension. (E24)

I don't do this kind of evaluation, usually I follow the elderly, the hypertensive, the diabetic [...]. (E3)

Never, not here and not in the academy. I only know HIPERDIA's booklet [...]. (E7)

Actually, we only have HIPERDIA [...]. (E23)

[...] here it's very complicated, because a lot of them (the elderly) only come here to get the medication for hypertension, diabetes, ask for some requisition, exchange prescription [...]. (E17)

[...] Not yet, most come only to see the doctor to update the prescription, so I have not yet [...]. (E10)

I don't perform at all, because it's really not the routine here, [...] I never got to do no. (E12)

However, it is evident that some nurses mentioned filling out the CSPI, checking the CC, but without reassessing it.

There is the old man's notebook that I usually fill out at their first appointment, but I don't keep reevaluating either. [...] (E15)

[...] in the old man's card [...] there is a field, which has there the measurement of the circumference of the left calf, if it is less than value, which if I am not mistaken is 35 or is 33, the risk of falling is higher. (E20)

From the testimonies, described and analyzed, it can be observed that most nurses have not had access to information, concepts and assistential practices about sarcopenia since graduation; and, after insertion in the professional field of $\mathrm{PHC}$, the situation worsens, because they report that they have not received training and updates on this problem, as can be seen below:

[...] my knowledge is little. [...] We never received any guidance from management to have some kind of training to track it there, so in a way it gets a little difficult. (E6)
So, since I had no knowledge of this disease, of this problem that affected the elderly, I did not work, [...] / had already heard the word, but I had no technique of any kind or anything turned to sarcopenia, so my difficulty was even to carry out the activity for lack of knowledge. (E8)

I think it's really a matter of knowledge because before... so, that wasn't a subject that we worked so hard on [...]. (E19)

\section{DISCUSSION}

The results of this study show that, in part, the lack of knowledge or fragmented, fragile, incomplete and ephemeral knowledge presented by the interviewees about sarcopenia comes from the absence of the subject since the formation process and later in the continued education of the nurse, a fact that is reflected in the lack of knowledge of the practices of screening.

It became clear that the different times of training portray a variety of experiences and experiences in the care practices of these nurses, because those who became professional years ago had no information on the problem of sarcopenia screening, which is now included more recently among the diseases affecting the elderly, being one of the items registered at CSPI, updated in 2017. It is worth mentioning that, among the participants, most have never participated in training in the area of gerontology. This reality found in the profile of these nurses may justify the lack of knowledge of them in relation to the problem of the investigation, making it impossible to implement the practice of screening for sarcopenia in the elderly.

It can be seen that, although most of the interviewees were unaware of the problem under study, some cognitions were congruent with the real definition of sarcopenia, characterized by a decline in muscle strength in association with the reduction in muscle mass ${ }^{(3)}$. Given the various functions exercised by muscle tissue, it is clear that sarcopenia will have a negative effect on the functional abilities of the elderly, increasing the risk of fragility and decline ${ }^{(22-23)}$. Studies show that the decline in muscle mass and muscle function increases mortality by up to 3.7 times $^{(24)}$ and increases the risk of fall by 2 times ${ }^{(26)}$, as well as increasing the risk of addiction in the elderly ${ }^{(25)}$.

In this context, the implementation, in clinical practice, of evaluation tools and screening tests for the early detection of diseases that directly interfere with the health situation of the elderly, such as sarcopenia, is paramount ${ }^{(14)}$. In the face of this, one realizes the importance of becoming aware of how much one knows about sarcopenia. It is through this process that people launch themselves into the search for new knowledge, which, when overcome, are replaced by others, in a constant process of making and remaking their own knowledge ${ }^{(26)}$.

It is noted that the weaknesses in the knowledge of nurses are reflected in the lack of knowledge of protocols, algorithms and practices aimed at screening for sarcopenia. Considering that the diagnosis of the disease is still difficult to obtain and gold standard methods are expensive and unavailable in clinical practice, especially in $\mathrm{PHC}$, tests with good sensitivity become indispensable because they allow the selection of those who can benefit from the confirmatory diagnosis ${ }^{(14)}$.

Faced with the rise of sarcopenia, the EWGSOP, in order to standardize the screening, diagnosis and determination of the severity of the disease, made available, in 2019, an algorithm based on the mnemonic sequence F-A-C-S (Find-Access-Confirm-Severity) 
to guide this process. As a first step in the investigation of sarcopenia, according to the algorithm, it is recommended to use the SARC-F questionnaire(3).

SARC-F is the main screening tool for sarcopenia and can be used in $\mathrm{PHC}^{(11)}$. A practical tool, quick and easy to use, which allows the identification of muscle strength decline, besides being a robust predictor of adverse health outcomes. The questionnaire is based on five self-referred questions about strength, walking, getting up from a chair, climbing a flight of stairs and falling ${ }^{(27)}$. However, in an attempt to improve the questionnaire, improving its sensitivity, a new version of the tool was proposed, by adding to SARC-F the CC evaluation (SARC-CaIF)(9,28).

In Brazil, when considering PHC, we still do not have specific instruments or protocols to track sarcopenia. Therefore, the nurse may use in his clinical practice the evaluation of CC, present in the CSPI, both to identify and to monitor the decline in muscle mass, in addition to being a useful assessment in monitoring body losses and early identification of sarcopenia(29-30).

However, despite being a relevant tool, it is observed that health professionals, especially the nurse, neglect to fill it out, in view of the unsatisfactory knowledge about the tool. This fact may be related to the low professional qualification to recognize the needs of the elderly population ${ }^{(31)}$, especially with regard to sarcopenia - after all, this is a relatively little publicized grievance in the national scientific environment, especially in the area of nursing.

In addition, a survey conducted with nurses working at PHC found that the booklet has been used inappropriately by professionals. The study observed that the tool was distributed to the population, but there was not the necessary qualification for its use $^{(32)}$. Allied to this, it is still possible to infer that, in addition to the lack of training, there is the resistance of professionals and the elderly in using it, the scarcity of scientific evidence on the use of this instrument and the difficulty of filling out by professionals ${ }^{(32-33)}$.

However, what is perceived, through the analysis of the work routine of professionals who work in this environment, is the scarcity of actions aimed at the elderly population. In a survey conducted with members of the Health Council of the Metropolitan Region of São Paulo, it is evident the fragility of the actions oriented to this population group, since $27 \%$ of the representatives showed the inexistence of specific actions/services to serve this segment, and $21 \%$ categorized the existing initiatives as incipient to serve the elderly population in a comprehensive manner ${ }^{(34)}$.

In the attention to this age group, in the context of PHC, some challenges must be overcome, such as the need to train nurses in order to propose strategies to modify this reality, in order to expand their practices, targeting them to the needs of the elderly ${ }^{(35-36)}$. In addition, it becomes substantial that the nurse surpasses the look focused on the complaints and illnesses presented, broadening their vision in order to recognize that health is the result of several factors ${ }^{(37)}$.

It was seen that, although there is an approximation between the nurse's performance and the sarcopenia screening, the deficit of information, concepts and assistance practices resulting from the graduation is maintained after the insertion in the PHC professional field, since the nurses did not receive training or updates on this problem. In view of the above, it is a great challenge for these professionals to expand their knowledge and practices regarding the aging process and sarcopenia, which makes it essential to build a culture of training for nurses and other members of the health team.

In this context, Permanent Health Education (PHE) is a strategy of change that assists in the qualification of assistance. It should be based on learning and on the perspective of transforming professional practices, through critical reflection on the problems faced, besides being based on the knowledge and experiences of each individual ${ }^{(19-20,38)}$. Thus, it is inferred that, in order to transform their practices, it is necessary that the nurse be in a constant movement of learning, dialogue and questioning, and that they be aware of the importance of reflexive practice, in order to be able, dissatisfied with their reality, to transform it. The more the individual reflects on their reality, the more they will become conscious, committed and able to intervene in the problems experienced in their work context $t^{(19-20,26,39)}$.

However, it is shown that the demand for PHE activities, most of the time, is part of the need of managers, who opt for immediate educational actions, with standardized content and usually dissociated from the demands of workers and users. In a recent literature review, the following weaknesses and difficulties in the implementation of PHE initiatives in PHC were observed: the overload of work, due to the insufficient number of professionals, the lack of initiatives and planning for the implementation of permanent education practices; and the lack of appreciation of this practice by managers and professionals ${ }^{(36)}$.

The importance of the qualification of nurses to work in the screening of sarcopenia in the elderly population is reiterated, bearing in mind that the implementation of screening instruments for this disease, within the PHC, becomes essential, as it contributes to the early identification of the elderly most vulnerable to develop the disease. It is reaffirmed that health professionals, especially nurses, have increasing possibilities to prevent, delay, treat and even reverse sarcopenia, through early and effective interventions $s^{(3,16)}$.

\section{Study limitations}

One limitation of the study was the high rate of refusals to participate in the research, which made it impossible to make generalizations about the analyzed object. It is believed that one of the reasons for the non-acceptance is due to the lack of knowledge of the subject by the participants.

\section{Contributions of the study to the nursing area}

The proposal to describe the knowledge and practices of the nurse about the screening of sarcopenia in the elderly in $\mathrm{PHC}$ will provide a basis for future investigations, considering the incipient scientific production on the object under study. Allied to this, it is expected to raise awareness among managers of the need for qualification of nurses regarding aspects related to sarcopenia, so that the limitations and gaps identified are remedied. The purpose of this study is to show the emergency in training professionals and to define protocols to support the implementation of tools that enable the screening of the disease within the scope of PHC, 
in order to allow the development of prevention, screening and early diagnosis actions.

\section{FINAL CONSIDERATIONS}

The description of the findings reveals that the knowledge of $\mathrm{PHC}$ nurses regarding sarcopenia in the elderly is incipient, fragile and incomplete, reflecting the lack of knowledge of practices, algorithms and protocols aimed at screening for the disease. It is noticeable that, even the CSPI being a facilitating instrument in the provision of quality assistance to the elderly, it is still being underused or unused by the nurses, because they do not know the instrument.

It was found that participants in the study feel limited by disability in their training and professional skills in a specific approach to sarcopenia and its forms of screening. In view of this, it is imperative that programs of continuing education be directed to these professionals, so that they can provide the elderly with holistic, integral and multidimensional assistance capable of preventing and screening for sarcopenia, as well as, in integration with other professionals, institute interventions.

Thus, nurses will be able to adopt new postures, more aware and able to transform their realities, through effective practices that make it possible to reach, in this way, a greater number of elderly people still in the pre-clinical phase of the disease, when they can prevent, minimize and/or reverse the impacts of sarcopenia on the health of the elderly population. In the perspective of making sarcopenia screening in PHC operational, the need for new studies on the practices developed to screen for sarcopenia in elderly people in different settings and participants is emphasized.

\section{REFERENCES}

1. Instituto Brasileiro de Geografia e Estatística (IBGE). Coordenação de População e Indicadores Sociais. Síntese de indicadores sociais: uma análise das condições de vida da população brasileira [Internet]. Rio de Janeiro: IBGE, 2016[cited 2018 May 10]. Available from: https:// biblioteca.ibge.gov.br/visualizacao/livros/liv101629.pdf

2. United Nations. World population aging 2017: highlights[Internet]. New York: United Nations, 2017[cited 2018 May 10]. Available from: https://www.un.org/en/development/desa/population/publications/pdf/ageing/WPA2017_Highlights.pdf

3. Cruz-Jentoft AJ, Bahat G, Bauer J, Boirie Y, Bruyère O, Cederholm T, et al. Sarcopenia: revised European consensus on definition and diagnosis. Age Ageing. 2019;48(1):16-31. doi: 10.1093/ageing/afy169

4. Bruyère $\mathrm{O}$, Beaudart $\mathrm{C}$, Ethgen $\mathrm{O}$, Reginster $\mathrm{JY}$, Locquet $\mathrm{M}$. The health economics burden of sarcopenia: a systematic review. Maturitas. 2019;119:61-69. doi: 10.1016/j.maturitas.2018.11.003

5. Cawthon PM, Lui LY, McCulloch CE, Cauley JA, Paudel ML, Taylor B, et al. Sarcopenia and Health Care Utilization in Older Women. J Gerontol. 2017;72(1):95-101. doi: 10.1093/gerona/glw118

6. Larsson L, Degens H, Li M, Salviati L, Lee Yl, Thompson W, Kirkland JL, et al. Sarcopenia: Aging-Related Loss of Muscle Mass and Function. Physiologic Rev. 2019;99(1):427-511. doi: 10.1152/physrev.00061.2017

7. Confortin SC, Ono LM, Barbosa AR, D'Orsi E. Sarcopenia e sua associação com mudanças nos fatores socioeconômicos, comportamentais e de saúde: Estudo EpiFloripa Idoso. Cad Saúde Pública. 2018;34(12):e00164917. doi: 10.1590/0102-311×00164917

8. Oliveira Neto L, Agrícola PMD, Andrade FLJP, Oliveira LP, Lima KC. Qual o impacto do Consenso Europeu no diagnóstico e prevalência de sarcopenia em idosos institucionalizados? Rev Bras Geriatr Gerontol [Internet]. 2017 [cited 2018 May 20];20(6):755-64. Available from: http:// www.scielo.br/pdf/rbgg/v20n6/pt_1809-9823-rbgg-20-06-00754.pdf

9. Barbosa-Silva TG, Menezes AMB, Bielemann RM, Malmstrom TK, Gonzalez MC. Enhancing Sarc-f: improving sarcopenia screening in the clinical practice. JAMDA. 2016;17(12):1136-1141. doi: 10.1016/j.jamda.2016.08.004

10. Ethgen O, Beaudart C, Buckinx F, Bruyère O, Reginster JY. The Future Prevalence of Sarcopenia in Europe: A Claim for Public Health Action. Calcif tissue int. 2017;100(3):229-234. doi: https://doi.org/10.1007/s00223-016-0220-9

11. Zanker J, Scott D, Reijnierse EM, Brennan-Olsen SL, Daly RM, Girgis CM, et al. Establishing an operational definition of sarcopenia in Australia and New Zealand: Delphi Method based consensus statement. J Nutr Health Aging. 2018;23(1):105-10. doi: 10.1007/s12603-018-1113-6

12. Dent $\mathrm{E}$, Morley JE, Vellas B. International clinical practie gidelines for sarcopenia (ICFSR):screening, diagnosis and menagement. J Nutr Health Aging. 2018;22(10):1148-61. doi: 10.1007/s12603-018-1139-9

13. Filippin LI. Rastreamento de sarcopenia na Atenção Primária em saúde: será uma utopia? Rev Inspirar - Mov Saúde [Internet]. 2015 [cited 2019 Aug 15];35(7):3-5. Available from: https://www.inspirar.com.br/wp-content/uploads/2015/10/rastreamento-artigo1_enviar_ed35_jul-ago-set-2015.pdf

14. Rubio J, Gracia MS. Ejercicios de resistencia en el tratamiento y prevención de la sarcopenia en ancianos: revisión sistemática. Gerokomos [Internet]. 2018 [cited 2019 Nov 8];29(3):133-7. Available from: http://scielo.isciii.es/pdf/geroko/v29n3/1134-928X-geroko-29-03-00133.pdf

15. Rendón R, Osuna IA. El papel de la nutrición en la prevención y manejo de la sarcopenia en el adulto mayor. Nutr Clin Med [Internet]. 2018 [cited $2018 \mathrm{Jul}$ 28];12(1):23-36. Available from: http://www.nutricionclinicaenmedicina.com/index.php/19-revista/149-5060

16. Yoshimura Y, Wakabayashi H, Yamada M, Kim H, Harada A, Arai H. Interventions for Treating Sarcopenia: A Systematic Review and MetaAnalysis of Randomized Controlled Studies. JAMDA. 2017;18(6):1-16. doi: 10.1016/j.jamda.2017.03.019

17. Salvà A, Serra-Rexach JA, Artaz I, Formiga F, Luque XR, Cuesta F et al. La prevalencia de sarcopenia en residencias de Espana: comparación de los resultados del estudio multicéntrico ELLI con otras poblaciones. Rev Esp Geriatr Gerontol. 2016;51(5):260-264. doi: 10.1016/j.regg.2016.02.004 
18. Ministério da Saúde (BR). Resolução № 466, de 12 de dezembro de 2012. Aprova normas regulamentadoras de pesquisas envolvendo seres humanos [Internet]. Brasília: Ministério da Saúde; 2012[cited 2018 Jul 28]. Available from: https://bvsms.saude.gov.br/bvs/saudelegis/ cns/2013/res0466_12_12_2012.html.

19. Freire P. Pedagogia da Autonomia: saberes necessários à prática educativa. São Paulo: Paz \& Terra; 2011. 144 p.

20. Freire P. Pedagogia do Oprimido. São Paulo: Paz \& Terra; 2013. 256 p.

21. Minayo MCS. O desafio do conhecimento: pesquisa qualitativa em saúde. São Paulo: Hucitec; 2014.408 p.

22. Bischoff-Ferrari HA, Orav JE, Kanis JA, Rizzoli R, Schlögl M, Staehelin HB, et al. Comparative performance of current definitions of sarcopenia against the prospective incidence off alls among community-dwelling seniors age 65 and older. Osteoporos Int. 2015;26:2793-802. doi: 10.1007/s00198-015-3194-y

23. Scott D, Johansson J, McMillan LB, Ebeling PR, Nordstrom P, Nordstrom A. Associations of Sarcopenia and Its Components with Bone Structure and Incident Falls in Swedish Older Adults. Calcif Tissue Int. 2019;105(1):26-30. doi: 10.1007/s00223-019-00540-1

24. Cheung C-L, Lam KSL, Cheung BMY. Evaluation of cutpoints for low lean massand slow gait speed in predicting death in the national health and nutrition examination survey 1999-2004. J Gerontol A Biol Sci Med Sci. 2016;71:90-5. doi: 10.1093/gerona/glv112

25. Malmstrom TK, Miller DK, Simonsick EM, Ferrucci L, Morley JE. SARC-F: a symptom score to predict persons with sarcopenia at risk for poor functional outcomes. J Cachexia, Sarcop Muscle. 2016;7:28-36. doi: 10.1002/jcsm.12048

26. Freire, P. Educação como prática libertadora. Rio de Janeiro: Paz \& Terra, 2013. 192 p.

27. Malmstrom TK, Morley JE. SARC-F: a simple questionnaire to rapidly diagnose sarcopenia. JAMDA. 2013;14:531-532. doi: 10.1016/j. jamda.2013.05.018

28. Yang M, Hu X, Xie L, Zhang L, Zhou J, Lin J et al. Screening Sarcopenia in Community-Dwelling Older Adults: SARC-F vs SARC-F Combined With Calf Circumference (SARC-CaIF). JAMDA. 2018;19(3):277. doi: 10.1016/j.jamda.2017.12.016

29. Ministério da Saúde (BR). Caderneta de Saúde da Pessoa Idosa [Internet]. Brasília: Ministério da Saúde; 2017[cited 2018 Jul 28]. Available from: http://portalarquivos2.saude.gov.br/images/pdf/2017/setembro/27/CADERNETA-PESSOA-IDOSA-2017-Capa-miolo.pdf.

30. Pagotto V, Santos KF, Malaquias SG, Bachion MM, Silveira EA. Calf circumference: clinical validation for evaluation of muscle mass in the elderly. Rev Bras Enferm. 2018;71(2):322-328. doi: 10.1590/0034-7167-2017-0121

31. Rigon E, Dalazen JVC, Busnello GF, Kolhs M, Olschowsky A, Kempfer SS. Experiências dos idosos e profissionais da saúde relacionadas ao cuidado pela estratégia saúde da família. Rev Enferm UERJ [Internet]. 2016 [cited 2018 Apr 27];24(5):e17030. Available from: http://www. facenf.uerj.br/v24n5/v24n5a18.pdf

32. Costa RRO, Bosco Filho J, Medeiros SM, Silva MBM. As rodas de conversa como espaço de cuidado e promoção da saúde mental. Rev Atenção Saúde. 2015;13(43):30-36. doi: 10.13037/rbcs.vol13n43.2675

33. Sá CMCP. Caderneta de saúde da pessoa idosa no olhar dos profissionais da estratégia de saúde da família[Dissertação]. Paraíba. Universidade Federal da Paraíba; 2016[cited 2019 Nov 10]. Available from: https://repositorio.ufpb.br/jspui/bitstream/tede/8732/2/ arquivototal.pdf

34. Côrte B, Kimura C, Ximenes MA, Nóbrega OT. Determinantes da atenção aos idosos pela rede pública de saúde, hoje e em 2030: o caso da Região Metropolitana de São Paulo. Saúde Soc [Internet]. 2017 [cited 2019 Nov 10];26(3):690-701. Available from:https://www.scielosp.org/ $\mathrm{pdf} / \mathrm{sausoc} / 2017 . v 26 \mathrm{n} 3 / 701 / \mathrm{pt}$

35. Dias FA, Gama ZAS, Tavares, DMS. Atenção primária à saúde do idoso: modelo conceitual de enfermagem. Cogitare Enferm [Internet]. 2017 [cited 2019 Nov 10];3(22):e53224. Available from: https://revistas.ufpr.br/cogitare/article/view/53224/pdf

36. Ferreira L, Barbosa JSA, Esposti CDD, Cruz MM. Permanent Health Education in primary care: an integrative review of literature. Saúde Debate. 2019;43(120):223-39. doi: 10.1590/0103-1104201912017

37. Tavares RE, Camacho ACLF, Mota CP. Ações de enfermagem ao idoso na estratégia saúde da família: revisão integrativa. Rev Enferm UFPE. 2017;11(2):1052-61. doi: 10.5205/reuol.10263-91568-1-RV.1102sup201722

38. Draper J, Clark L, Rogers J. Managers' role in maximizing investment in continuing professional education. Nurs Manag [Internet]. 2016 [cited 2019 Oct 18];22(9):30-36. Available from: http://journals.rcni.com/doi/abs/10.7748/nm.22.9.30.s29

39. Mendonça FTNF, Santos AS, Buso ALZ, Malaquias BSS. Health education with older adults: action research with primary care professionals. Rev Bras Enferm. 2017;70(4):792-9. doi: 10.1590/0034-7167-2016-0349 